\title{
New Zealand indigenous Myrtaceae in foreign botanic gardens: testing the sentinel plant concept for biosecurity risk assessment
}

\author{
Kirsty S.H. Boyd-Wilson ${ }^{1,3}$, M. Virginia Marroni ${ }^{1,3}$, Mark R. McNeill2,3 and David A.J. Teulon ${ }^{1,3, *}$ \\ ${ }^{1}$ The New Zealand Institute for Plant and Food Research Ltd, Private Bag 4704, Christchurch 8140, New Zealand \\ ${ }^{2}$ AgResearch, Lincoln, Private Bag 4749, Christchurch 8140, New Zealand \\ ${ }^{3}$ Better Border Biosecurity (B3) (www.b3nz.org.nz) \\ *Corresponding author: David.Teulon@plantandfood.co.nz
}

(Original submission received 24 November 2020; accepted in revised form 25 January 2021)

\begin{abstract}
The use of sentinel or expatriate plants is a growing concept for risk assessment in plant biosecurity. This approach involves ascertaining the presence and impact of pests and pathogens on plants foreign to a given location but planted in international botanic gardens or arboreta. The data obtained provide information on the potential pest status of these pests and pathogens, as invasive alien species (IAS), to plant species in their native or indigenous range. Assessment of the biosecurity threat from IAS for indigenous plants not found within the geographic distribution of these pests and pathogens is challenging, however, as they may be relatively taxonomically distinct from plants found in the distribution of the IAS and can be in different climates and environments. We examine the sentinel/expatriate concept in relation to risk assessment for myrtle rust (Austropuccinia psidii) on New Zealand Myrtaceae on these plants found in botanic gardens and arboreta outside New Zealand. Between September 2017 and September 2018, we identified and then contacted 65 botanic gardens or arboreta that putatively had New Zealand Myrtaceae and were within the known distribution of myrtle rust. We asked for information on the presence of New Zealand Myrtaceae species in their collections and whether these plants were infected by myrtle rust. Sixteen gardens/arboreta responded; most were in Australia or the United States. Only one of these gardens provided information that was useful for biosecurity risk assessment for myrtle rust on New Zealand Myrtaceae. The results are discussed in the context of plant biosecurity risk assessment and the broader sentinel/expatriate plant concept.
\end{abstract}

Keywords sentinel plants, expatriate plants, Myrtaceae, myrtle rust, biosecurity, risk assessment

\section{INTRODUCTION}

With globalisation facilitating the spread of many organisms around the world (Early et al. 2016), Invasive Alien Species (IAS) are having severe effects on the environments they invade, including in New Zealand (Brockerhoff et al. 2010, Goldson et al. 2015). Many countries have incorporated various biosecurity measures across the invasion pathway (or biosecurity continuum) to mitigate these impacts. The more robust systems comprise a range of measures including: risk assessment; pathway risk management; surveillance; containment; eradication; and, if these fail and the organism establishes, long-term pest management (e.g. Ministry for Primary Industries 2018, Australian Department of Agriculture 2019).

While relatively isolated from other land masses, New Zealand places very high importance on biosecurity due to its reliance on bio-economic sectors (Government Industry Agreement for Biosecurity Readiness and Response 2020) and its unique indigenous flora and fauna characterised by a high degree of endemism (Department of Conservation 2016). Risk assessment is the cornerstone of this biosecurity system, as it provides information on the relative threats from different organisms and informs optimal investment of resources at critical points (e.g. pathway management, surveillance, eradication) of the invasion pathway. New Zealand's valuable pastoral, forest, cropping and horticultural systems comprise mostly of introduced animals and plants, and risk assessment for invasive pests, pathogens and weeds not found in New Zealand are often informed from similar systems outside New Zealand (e.g. Ballingall \& Pambudi 2017). However, biosecurity risk assessments for New Zealand's indigenous flora and fauna are much more difficult to undertake as these valuable species are mostly restricted to the New Zealand archipelago (e.g. Teulon et al. 2019).

In 2004, the Better Border Biosecurity (B3) (www.b3nz. org.nz) research consortium in New Zealand initiated a project to explore whether New Zealand sentinel or 
expatriate plantings (i.e. New Zealand indigenous plant species in foreign botanic gardens or arboreta) could be used for biosecurity risk assessment for plant species found in New Zealand (e.g. Aalders et al. 2006, Better Border Biosecurity 2007, Fagan et al. unpublished data ${ }^{1}$ ).

Since then, this concept (sentinel/expatriate plants) has developed into an internationally recognised approach for risk assessment and surveillance (Britton et al. 2010, Groenteman et al. 2015, Barham et al. 2016, Paap et al. 2017, Eschen et al. 2018, Mansfield et al. 2019). In particular, the International Plant Sentinel Network (IPSN) (IPSN 2014) has facilitated collaboration amongst institutes around the world, with a focus on linking botanic gardens and arboreta, national plant protection organisations and plant health scientists, to provide an early warning system of new and emerging pest and pathogen risks (Barham et al. 2016).

Myrtle rust, caused by the pathogen Austropuccinia psidii (G.Winter) Beenken (formerly Puccinia psidii), is a disease of many plant species belonging to the Myrtaceae. It is thought to have originated from Central and South America (Glen et al. 2007) but it has established in many regions around the world (Centre for Agriculture and Biosciences International, CABI 2019). It was found on the New Zealand mainland for the first time in May 2017 and at the time of this study was present across most of the North Island and upper areas of the South Island (Ho et al. 2019). At least 440 plant species from the Myrtaceae are known to be hosts to myrtle rust (CABI 2019) and it has become a serious threat to a number of plant species and plant ecosystems (Coutinho et al. 1998, Carnegie 2012, Soewarto et al. 2018, Berthon et al. 2018, Carnegie \& Pegg 2018, CABI 2019). New Zealand has 27 currently recognised species of indigenous Myrtaceae, of which most are endemic to NZ (Landcare Research 2020). There is considerable concern over the impact of myrtle rust on New Zealand indigenous Myrtaceae including pōhutukawa (Metrosideros excelsa Sol. ex Gaertn.), mānuka (Leptospermum scoparium J.R.Forst. \& G.Forst.), rātā (Metrosideros spp.) and kānuka (Kunzea spp.). These are all 'iconic' species due to their various economic, environmental, social and cultural values (Clark 2011, Teulon et al. 2015, Black et al. 2018, Beresford et al. 2019). Prior to its establishment in New Zealand, Clark (2011) identified moderate economic and variable environmental impacts and recognised moderate to high potential socio-cultural consequences were myrtle rust to become established in New Zealand. The aim of this study was to assess the usefulness of the sentinel/expatriate plant concept for risk assessment using New Zealand Myrtaceae and myrtle rust as a plant patho-system model. In doing so, we intended to explore the ease of obtaining information on myrtle rust infection and impact data on New Zealand Myrtaceae growing in foreign gardens and arboreta, and the use of these data to provide supplementary information

${ }^{I}$ Fagan L, Bithell S, Fletcher J, Cromey M, Elder S, Martin N, Bell N, Aalders L, Cousins K, Barratt B, Ferguson C, Kean J, Phillips C, McNeil M, Barron M, Dick M, Kay N, Alcaraz S, Kriticos D 2008. Evaluating the 'Expatriate'Plant concept: Can we predict invasive threats to New Zealand natural ecosystems by focussing our efforts overseas. Unpublished report. Better Border Biosecurity. for the risk assessment. As the study was occurring at the same time that myrtle rust was spreading through New Zealand, we also planned to compare pathogen and disease information obtained from foreign locations with that obtained from New Zealand locations, to assess the utility of this approach for risk assessment.

\section{MATERIALS AND METHODS}

Our approach was to examine New Zealand indigenous Myrtaceae in international botanic gardens and arboreta (henceforth referred to as international gardens) within the known distribution of myrtle rust. Originally we intended to examine New Zealand plant species from the Myrtaceae family with a putatively wide range of susceptibility to myrtle rust (i.e. Leptospermum scoparium (mānuka) (putatively low susceptibility), Metrosideros excelsa (pōhutukawa) (putatively medium susceptibility), Lophomyrtus spp. (ramarama) (putatively high susceptibility) based on field observations in Australia (J. Edwards, pers. comm.) and initial observations in New Zealand (Beresford et al. 2019)). However, as the research developed, it became clear that it was not possible to make observations on this range of species at given locations given the limited data set of infected plants outside New Zealand (see below).

\section{Distribution of myrtle rust}

The reported global distribution of myrtle rust as of July 2017 was established (see CABI 2019) where information was obtained for countries, and for provinces and states of larger countries, such as Australia, the United States of America and China.

\section{Location of New Zealand Myrtaceae}

The B3 Expatriate New Zealand Plant Database (B3 2007) and two databases (PlantSearch and GardenSearch) operated by Botanic Gardens Conservation International (BCGI) (BGCI 2017a, b) were examined to establish the location of New Zealand indigenous Myrtaceae in international gardens within the known distribution of myrtle rust. Initial searches were made through the PlantSearch database but these required further requests to individual gardens, which proved to be unsuccessful (see below). Thereafter, the 'Advanced Search' feature of the BGCI GardenSearch was used to identify international gardens with New Zealand Myrtaceae within the myrtle rust distribution for each country. We undertook an initial search of the internet for evidence of New Zealand plants being grown in foreign locations with little success (M. Gee, unpublished data).

\section{Contacting botanic gardens and arboreta}

After initial screening of international gardens from the above sources and based on details of plant collection information provided in the GardenSearch database and individual garden websites, a subset of gardens was identified and then contacted via email using the contacts found on their website, in either English (Australia, Austria, Hungary, Japan, South Africa, Switzerland and the United States of America) or Spanish (Argentina, Brazil, Colombia, Costa Rica, Dominican Republic, Guatemala, 
Mexico, Panama, Puerto Rico, Venezuela), from September 2017 to September 2018. Each garden contact was asked: (1) whether they knew if myrtle rust was present in the locality of their garden; (2) whether they had New Zealand Myrtaceae plants in their collection; (3) whether myrtle rust was found on any New Zealand Myrtaceae in their collection; and (4) whether they attempted to manage myrtle rust in their garden? A reminder email was sent to gardens that had not responded approximately one month after the first email. We report on the scientific plant names provided to us by the respondents who may or may not have updated them based on new taxonomy found in recent literature (e.g. Kunzea spp. for de Lange 2014).

\section{Additional information}

For some gardens, additional information was obtained through supplementary emails, including accession dates and provenance of plants, and the presence and impact of myrtle rust on other plants in the respective gardens. Visits were made to a number of gardens in Australia due to their proximity to New Zealand, the size of their New Zealand plantings and the presence of myrtle rust. Data from all sources were collated but, owing to the limited amount of instructive information obtained, that the study was a survey with a potentially non-random sample of gardens, formal statistical analysis would have added little value and was not appropriate (R Butler pers. comm.).

\section{RESULTS}

\section{Distribution of myrtle rust}

Twenty-six countries were recorded as having myrtle rust in 2017 (CABI 2019).

\section{Location of New Zealand Myrtaceae}

Three international botanic gardens/arboreta within current myrtle rust distribution areas that have plantings of New Zealand Myrtaceae were identified from the B3 Expatriate New Zealand Plants Database (B3 2007). These were the Brisbane Botanic Gardens, Brisbane, Queensland, Australia, the Royal Tasmanian Botanical Gardens, Hobart,
Tasmania, Australia and the Harold L. Lyon Arboretum, Honolulu, Hawai'i. Searches of PlantSearch (BGCI 2017a) identified 78 matches for $M$. excelsa and its cultivars, and 15 matches for cultivars derived from Lophomyrtus bullata Burrett. However, this database did not provide publicly available information (or filtering) by country so it was not possible to tell if these plants were growing in New Zealand or elsewhere. The PlantSearch website contains a 'send request' function, which enables emails requesting more information to be sent to botanic gardens. Our use of this function resulted in just one response from 14 gardens for L. bullata so we did not interrogate PlantSearch further for additional New Zealand Myrtaceae genera/species.

Interrogation of BGCI's GardenSearch generated a total of 195 gardens from the 26 countries previously identified as having myrtle rust. A subset of 65 of these international gardens (i.e. gardens within the distribution of myrtle rust and the likelihood of them having New Zealand plant species) were contacted initially by email.

\section{Responses from botanic gardens and arboreta}

About 30\% of the 65 international gardens responded with information on plants in their botanic gardens, with 14 gardens in Australia, six gardens in the United States (including two in Hawai'i) and one in Japan, indicating that they had New Zealand Myrtaceae in their collections (Table 1; Appendix 1). Some gardens responded with incomplete information. Some gardens had substantial New Zealand collections (e.g. Royal Botanic Gardens Victoria (RBGV, Melbourne); Royal Botanic Garden Sydney (RBGS); San Francisco Botanical Garden), some had just a few plants, while others had none (Appendix 1). Some gardens had experienced myrtle rust in their gardens in the past but only one garden (RBGV, Melbourne) could provide any information on myrtle rust on New Zealand Myrtaceae, and this was limited.

\section{Additional information}

Information gained from visits to the RBGV, Melbourne (30 November 2017) and RBGS (9 March 2018), and subsequent correspondence, provided additional insight into the use

Table 1 International botanic gardens and arboreta considered in this study

\begin{tabular}{lcl}
\hline Botanic gardens or arboreta & Number & Comments \\
\hline Countries with myrtle rust (MR) & 26 & CABI 2017 \\
Gardens within those countries & 195 & BGCI GardenSearch \\
Gardens contacted $^{1}$ & 65 & From 17 countries (see text) \\
Gardens responded & 21 & Australia (14), USA (6), Japan (1) \\
Gardens with New Zealand (NZ) Myrtaceae & 14 & Australia (8), USA (5), Japan (1) \\
Gardens recorded with NZ Myrtaceae and MR & 6 & Australia (4), USA (2) \\
Gardens recorded with NZ Myrtaceae, MR and useful & 1 & Melbourne Gardens, RBGV \\
observations on impact & & \\
\hline
\end{tabular}

${ }^{1}$ All by email, some followed up by telephone and two by visits 
of botanic gardens for risk assessment with our model system of myrtle rust and New Zealand Myrtaceae. RBGV, Melbourne, has had several species of Australian Myrtaceae infected with myrtle rust from time to time (P. Symes, pers. comm.). Reinfection was thought to have resulted from sources outside the garden. RBGV monitored for myrtle rust every week and carried out regular spraying when it occurred. A range of New Zealand Myrtaceae were found in the garden (Table 2). It was assumed that most of these plants had been sourced from New Zealand originally but the provenance was not known. Of these New Zealand species, only Lophomyrtus spp. had been observed to be infected with myrtle rust between 2013 and 2019. Because only early and treated infections were observed, the full impact on this species could not be ascertained (P. Symes, pers. comm.). One L. bullata and several L. obcordata (Raoul) Burrett specimens were used as sentinel plants for myrtle rust surveillance within the RBGV (P Symes, pers. comm.).

Myrtle rust was recorded occasionally in RBGS on three Australian plant species: Austromyrtus dulcis, Rhodamnia argentea and Rhodamnia rubescens (which was removed), and on Syzygium jambos, although drought conditions probably reduced myrtle rust incidence in years prior to the study (B. Summerell, pers. comm.). Several New Zealand species are planted in RBGS (Table 2) but no myrtle rust symptoms were recorded on them (B. Summerell, pers. comm.).

Table 2 Species* and number of plants of New Zealand Myrtaceae found in the Royal Botanic Garden Victoria, Melbourne (P. Symes \& K. Roud, pers. comm.) and the Royal Botanic Garden Sydney (B. Summerell, pers. comm.).

\begin{tabular}{lrr}
\hline Species & RBGS & RBGV \\
\hline Kunzea ericoides $^{1}$ & 2 & 48 \\
Leptospermum scoparium & 13 & 6 \\
Lophomyrtus $\times$ ralphii & 7 & 9 \\
Lophomyrtus bullata & 0 & 1 \\
Lophomyrtus obcordata & 0 & 4 \\
Metrosideros carminea & 2 & 12 \\
Metrosideros excelsa & 11 & 0 \\
Metrosideros kermadecensis & 3 & 0 \\
Metrosideros perforata & 0 & 8 \\
Metrosideros robusta & 0 & 2 \\
Metrosideros umbellata & 3 & 1 \\
\hline
\end{tabular}

* Scientific plant names are reported as provided to us by the respondents who may or may not have updated them based on new taxonomy found in recent literature (e.g. Kunzea spp. for de Lange 2014)

\footnotetext{
${ }^{1}$ Possibly Kunzea phylicoides for RGBV (P. Symes, pers. comm.). A major revision of the Kunzea genus was undertaken by de Lange (2104), which may or may not have been accounted for by RGBS and RBGV.
}

\section{DISCUSSION}

In this study we tested the sentinel/expatriate plant concept for biosecurity risk assessment in the context of the detection of new host associations and damage for plant species to a pathogen with which it has not co-evolved (Fagan et al. unpublished data ${ }^{1}$, Britton et al. 2010, Eschen et al. 2018, Mansfield et al. 2019). In particular, we investigated New Zealand Myrtaceae species grown outside their natural home range in foreign locations, where they were potentially exposed to myrtle rust found in that location, to assess whether the pathogen has the potential to infect and cause damage to these plants or not. The advantages, disadvantages, and optimal use of the sentinel/expatriate plant approach are currently being explored more generally in the broader literature. Here we focus on the specific learnings we obtained from undertaking this study.

\section{Model system}

The New Zealand indigenous Myrtaceae/myrtle rust study had several compelling features for examining the sentinel/expatriate plant concept, as myrtle rust is a generalist pathogen with a wide host range and geographic distribution that likely infects New Zealand plant species that are planted around the world in botanic gardens or arboreta. Additionally, the invasive pathogen is sufficiently important that a considerable amount of relevant published and unpublished information exists on its distribution, host range, and impact. Furthermore, we had hoped to verify risk assessment predictions with field observations, using targeted indigenous trees within New Zealand as myrtle rust spread throughout NewZealand after its recent incursion and establishment (Ho et al. 2019). Prior to finding myrtle rust in New Zealand, Teulon et al. (2015) recorded that nine New Zealand indigenous species from four genera were reported to be susceptible to myrtle rust based on observations made in the laboratory and in the field in Australia and Hawai'i, but the degree of this susceptibility was not known. Loope (2010) reported that a few individuals of pōhutukawa (M. excelsa) in the Lyon Arboretum in Hawai'i were seriously affected by myrtle rust. More recently the susceptibility of New Zealand Myrtaceae has been assessed by inoculation of seedlings under controlled conditions in Australia (Beresford et al. 2019, Soewarto et al. 2019, Smith et al. 2020).

Despite the putatively ideal model system, our study provided very little information that was useful to assess the potential risk of myrtle rust for New Zealand indigenous Myrtaceae. This was primarily because we found only one foreign botanic garden (i.e. RBGV, Melbourne) with relevant information on myrtle rust infestation on New Zealand Myrtaceae. In essence we found some information that indicated Lophomyrtus spp. might be susceptible to myrtle rust, but this susceptibility was already known from plants in Australia: a cultivar of Lophomyrtus was used as an indicator plant for the earlier Australian myrtle rust incursion (J Edwards, pers. comm.). Furthermore, because of the limited amount of information obtained we were unable to compare and contrast this data with myrtle rust infection of New Zealand Myrtaceae (Beresford et al. 2019) as the New Zealand incursion progressed. 


\section{Risk assessment for indigenous plants}

In the New Zealand biosecurity context, risk assessment for indigenous plant species in general from invasive pests and diseases not yet found in New Zealand is challenging because many of these plants are not commonly grown outside New Zealand and because of the high endemism of New Zealand's flora (Allan 1961). A recent attempt to assess the biosecurity risk of Halyomorpha halys Stål (brown marmorated stink bug or BMSB) to New Zealand indigenous plants is a case in point (Teulon et al. 2019). Despite extensive published information on the plant hosts and impact of BMSB from international sources, many New Zealand indigenous species (including taonga plants - those highly prized to indigenous Māori) could not be categorised as to their potential risk from BMSB (Teulon et al. 2019).

\section{The broader sentinel plant concept}

Mansfield et al. (2019) provided a list of risk assessment outcomes from a range of published 'in situ' and 'planned plantings' sentinel plant approaches. From a New Zealand perspective, it seems unlikely that the 'planned planting' approach will become a common and pragmatic operational solution for biosecurity risk assessment owing to the associated costs of planting New Zealand indigenous species in sufficient quantities in foreign locations and/ or the increasing awareness of biosecurity risks from extensive foreign plantings of non-native species within those geographic locations. However, there may be some examples where the potential biosecurity risk of a particular organism and lack of alternatives may make 'planned plantings' a viable option. In comparison, several 'in situ' sentinel plant studies in international botanical gardens or arboreta have generated noteworthy information on the hosts (and sometimes damage) of plant pests and diseases (see Tomoshevich et al. 2013, Groenteman et al. 2015, ScottBrown et al. 2017, Redlich et al. 2019). In particular, the Xylella fastidiosa / New Zealand indigenous plant species system in California, has provided important information on the host status of this plant pathogen on a range of New Zealand indigenous plant species (Groenteman et al. 2015).

\section{Potential limitations}

International botanic gardens and arboreta provide a unique opportunity to assess the pests and pathogens found inhabiting and damaging foreign plant species outside their native distribution. However, for pathogens, the information gained from these assessments must be treated with some caution as foreign botanic gardens and arboreta will not necessarily reflect the conditions or factors represented in the disease triangle, a conceptual model that shows the interactions between the environment, the host and an infectious agent (Scholthof 2007). The host plant and plantpathogen factors are represented in foreign gardens but the environmental conditions may not be. In our study, only one (RBGV, Melbourne) of the 14 foreign gardens (Appendix 1) where we found New Zealand Myrtaceae, had a sufficiently similar climate match index (CMI) for applying the criteria suggested by Fagan et al. (unpublished data) ${ }^{1}$ to recommend it for future prioritised monitoring of New Zealand plants in an sentinel/expatriate context. The garden identified by Fagan et al. (unpublished data) ${ }^{1}$ with the most similar climate match to New Zealand (Royal Tasmanian Botanical Garden, Hobart) was not infected with myrtle rust (CABI 2019) at the time of this study. Despite these caveats, host status records may still be useful in the biosecurity context.

Additionally, botanic gardens have limited (and sometimes unrecorded) provenances of plant species. This could be particularly important information where species delineations or identifications have changed or are in debate. Following a recent revision (de Lange 2014), Kunzea ericoides (A.Rich.) Joy Thomps. is endemic to New Zealand (rather than indigenous to New Zealand and Australia) and uncommon in cultivation: plants named as $K$. ericoides and grown in botanic gardens and arboreta could instead be one of many species segregated from the $K$. ericoides complex, especially K. robusta de Lange \& Toelken or perhaps K. serotine de Lange \& Toelken. Leptospermum scoparium in the current sense is also shared with Australia, particularly Tasmania, but there is evidence that in the strict sense this species is endemic to New Zealand: further study of L. scoparium agg. is needed (P. de Lange, pers. comm.). Gardens may only have representatives of a particular growth stage, for example mature plants, which may not be highly susceptible to a particular disease compared with younger plants (or young growth is high in the canopy and out of reach). Furthermore, botanic gardens often undertake management of diseases such as removing susceptible cultivars and species and applying other controls (e.g. pesticide applications), thereby minimising the apparent impact of a particular pathogen. For example, RBGV, Melbourne carried out fungicide spraying when myrtle rust was observed within the garden. Another confounding factor could be the strain or biotype of the pathogen found in a particular garden. In the case of myrtle rust, there are several strains of the pathogen $A$. psidii found in regions of the world (CABI 2019) although it is generally a so-called monophyletic 'pandemic' strain that has spread throughout the world and is found in Australia, California, Hawai'i and New Zealand.

\section{Survey response}

Overall, the majority of responses in our study came from gardens in Australia and the United States despite our attempt to target gardens in Spanish-speaking countries by emailing requests to them in Spanish. The lack of response from some countries (e.g. Japan, Brazil) may have been influenced by the request for information in only English or Spanish. The positive response from Australian gardens may have reflected the heighted awareness of myrtle rust in that country as a result of its relatively recent incursion, the closer professional ties between gardens in the two countries through Botanic Gardens Australia New Zealand (BGANZ), and possibly a presentation at the BGANZ Annual Congress in October 2017 on the sentinel plant concept (Fraser 2017). Lack of response from other gardens may have been due to incorrect or poorly attended institutional email addresses and the lack of capacity or capability to be able to respond to our relatively detailed questions. Capability issues may have included not being aware what myrtle rust was or how to identify it, or even whether it was in their gardens at low rates of infestation. For example, 
we understand that many South African botanic gardens are staffed by volunteers (T. Paap, pers. comm.) who would not have familiarity with myrtle rust. Correct identification of important pests and diseases is a generic issue in risk assessment. Botanical institutions have much higher expertise and more resources in horticulture and plant taxonomy than in mycology or plant pathology (Kramer \& Hird 2011). In subsequent expatriate sentinel studies on Xylella, where we have used the BCGI IPSN co-ordinator as an intermediary for requesting information, there was a similar (c. 30\%) response from botanical institutions (see Marfleet \& Sharrock 2020). We also note that no botanical institutions from South America or South Africa responded to an earlier IPSN-related survey (Kramer \& Hird 2011).

\section{Alternative approaches to risk assessment}

New Zealand Myrtaceae exemplify a distinctive biosecurity challenge because of: the importance of these plant species within natural systems; their cultural and spiritual value to Māori (taonga); their iconic status to the New Zealand public in general; and the value of Leptospermum scoparium to the mānuka honey industry (Teulon et al. 2015, Black et al. 2018). The value proposition for mitigating the impact of myrtle rust on Myrtaceae has underpinned a more conventional approach to risk assessment through the inoculation of seedlings under controlled conditions (Beresford et al. 2019, Smith et al. 2020). In this case, the research was undertaken under quarantine in Australia, with extensive prior consultation with Māori. While this approach will no doubt provide useful information on the relative susceptibility of New Zealand Myrtaceae to myrtle rust, it has its own limitations because the threat of myrtle rust to seedlings in the laboratory does not necessarily reflect the threat from myrtle rust to mature plants in the field (G. Pegg, pers. comm.). Laboratory experiments involve exposure of the host (usually at a highly susceptible stage) to high pathogen inoculum rates under optimum environment conditions, which do not necessary reflect what occurs in the natural environment. Such a risk assessment approach is likely to be undertaken only for key indigenous plant species because of the investment required for research, compliance and Māori consultation, and/or where it can be included in a larger programme targeting other plant species. For many plant species, a range of pest risk assessment processes is likely to prove beneficial.

\section{SUMMARY}

Our study provides one of the few documented attempts to investigate the incidence and impact of a potentially invasive disease on sentinel expatriate plants in foreign botanic gardens and arboreta, and helps to illustrate some of the challenges of this process. The B3 New Zealand Plant Sentinel Database (B3 2017) provided some useful links and information on gardens with New Zealand plants but the data obtained from the BGCI GardenSearch were much more comprehensive.

Methods for assessing the potential impact of invasive species on indigenous plant species are limited, so all approaches should be considered. Despite the limited results found in this study, there is continued interest in the sentinel/expatriate concept for biosecurity risk assessment, with a number of studies showing that the concept can be useful for assessing plant host associations, including damage, in botanic gardens and arboreta. The challenge for biosecurity risk assessors will be to determine for which IAS/plant systems this approach works best, and how to optimise the information exchange from source gardens.

\section{ACKNOWLEDGEMENTS}

We thank the colleagues from the 21 botanical gardens and arboreta who responded to our request for information, especially Peter Symes (RBGV) and Brett Summerell (RBGS). The work was carried out in association with the International Plant Sentinel Network (Euphresco project 2016-I-224) and with valuable assistance from the project co-ordinators Suzanne Sharrock, Katherine O'Donnell and Kate Marfleet (all BGCI). We thank Megan Gee (Plant \& Food Research) for assistance in searching the internet. The manuscript was improved with reviews from Lucia Ramos Romero (Plant \& Food Research), Ronny Groenteman (Manaaki Whenua - Landcare Research), Katherine O’Donnell (BGCI) and two anonymous reviewers.

\section{REFERENCES}

Aalders LT, Bell NL, Barratt BIP, Neilson R 2006. Using expatriate New Zealand flora as predictors of nematode threats to New Zealand natural ecosystems. In XXVIII European Society of Nematologists International Symposium. Pp. 155.

Allan HH 1961. Flora of New Zealand. RE Owen, Wellington. $1085 \mathrm{p}$.

Australian Department of Agriculture (DA). 2019. Biosecurity in Australia. Department of Agriculture, Canberra, Australia Accessed July 2019 from http:// www.agriculture.gov.au/biosecurity/australia

Ballingall J, Pambudi D 2017. Quantifying the economic impacts of a brown marmorated stink bug incursion in New Zealand. A dynamic Computable General Equilibrium modelling assessment. New Zealand Institute of Economic Research. Wellington, New Zealand.

Barham E, Sharrock S, Lane C, Baker R 2016. The International Plant Sentinel Network: A tool for Regional and National Plant Protection Organizations. EPPO Bulletin 46: 156162. https://doi.org/10.1111/epp.12283

Beresford R, Smith G, Ganley B, Campbell R 2019. Impacts of myrtle rust in New Zealand since its arrival in 2017. New Zealand Garden Journal 22(2): 5-10.

Berthon K, Esperon-Rodriguez M, Beaumont LJ, Carnegie AJ, Leishman MR 2018. Assessment and prioritisation of plant species at risk from myrtle rust (Austropuccinia psidii) under current and future climates in Australia. Biological Conservation 218: 154-162. https://doi. org/10.1016/j.biocon.2017.11.035

Better Border Biosecurity (B3). 2007. Expatriate NZ plants database. Accessed July 2019 from http://b3.net.nz/ expat/view.php 
Black A, Mark-Shadbolt M, Garner G, Green J, Malcolm T, Marsh A, Ropata H, Waipara N, Wood W 2018. How an indigenous community responded to the incursion and spread of myrtle rust (Austropuccinia psidii) that threatens culturally significant plant species - a case study from New Zealand. Pacific Conservation Biology 25(4): 348-354. https://doi.org/10.1071/PC18052

Botanic Gardens Conservation International (BGCI). 2017a. PlantSearch online database. Botanic Gardens Conservation International. Richmond, U.K. Accessed December 2020 from https://tools.bgci.org/plant search.php

Botanic Gardens Conservation International (BGCI) 2017b. GardenSearch online database. Botanic Gardens Conservation International. Richmond, U.K. Accessed December 2020 from https://tools.bgci.org/garden search.php

Britton KO, White, P, Kramer A, Hudler G 2010. A new approach to stopping the spread of invasive insects and pathogens: Early detection and rapid response via a global network of sentinel plantings. New Zealand Journal of Forestry Science 40: 109-114.

Brockerhoff EG, Barratt BIP, Beggs JR, Fagan LL, Kay MK, Phillips CB, Vink CJ 2010. Impacts of exotic invertebrates on New Zealand's indigenous species and ecosystems. New Zealand Journal of Ecology 34(1): 158-174.

Carnegie AJ 2012. The impact and management of Eucalyptus/guava rust in commercial forestry and native environments in Brazil and the USA: lessons for Australia. Gottstein Fellowship Report. J. W. Gottstein Memorial Trust Fund, Clayton South, Victoria. 57 p.

Carnegie AJ, Pegg GS 2018. Lessons from the incursion of myrtle rust in Australia. Annual Review of Phytopathology 56: 457-478. https://doi.org/10.1146/ annurev-phyto-080516-035256

Centre for Agriculture and Biosciences International (CABI). 2019. Austropuccinia psidii (myrtle rust). Invasive Species Compendium. Accessed April 2019 from https://www.cabi.org/isc/datasheet/45846

Clark S 2011. Risk analysis of the Puccinia psidii/Guava Rust fungal complex (including Uredo rangelii/Myrtle Rust) on nursery stock. Ministry of Agriculture and Forestry. Wellington. https://www.nzffa.org.nz/assets/452/ puccinia-psidii-on-nursery-stock-ra.pdf

Coutinho T, Wingfield M, Alfenas A, Crous P 1998. Eucalyptus rust: a disease with the potential for serious international implications. Plant Disease 82: 819-825. https://doi. org/10.1094/PDIS.1998.82.7.819

de Lange P 2014. A revision of the New Zealand Kunzea ericoides (Myrtaceae) complex. PhytoKeys 40: 1-185.

Department of Conservation (DOC) 2016. New Zealand Biodiversity Action Plan 2016-2020. Department of Conservation. Wellington, New Zealand. https://www. doc.govt.nz/globalassets/documents/conservation/ new-zealand-biodiversity-action-plan-2016-2020.pdf

Early R, Bradley BA, Dukes JS, Lawler JJ, Olden JD, Blumenthal DM, Gonzalez P, Grosholz ED, Ibañez I, Miller LP, Sorte CJB, Tatem AJ 2016. Global threats from invasive alien species in the twenty-first century and national response capacities. Nature Communications 7:
No. 12485. https://doi.org/10.1038/ncomms12485

Eschen R, O'Hanlon R, Santini A, Vannini A, Roques A, Kirichenko N, Kenis M 2018. Safeguarding global plant health: the rise of sentinels. Journal of Pest Science 92: 29-36. https://doi.org/10.1007/s10340-018-1041-6

Fraser G 2017. BGANZ's potential role in the International Plant Sentinel Network. 8th BGANZ Congress. Adelaide, South Australia. 24-26 October 2017. https://www. bganz.org.au/assets/uploads/2017/12/Greg-Fraser BGANZs-potential-role-in-the-International-PlantSentinel-Network.pdf

Glen M, Alfenas AC, Zauza EAV, Wingfield MJ, Mohammed C 2007. Puccinia psidii: a threat to the Australian environment and economy a review. Australasian Plant Pathology 36: 1-16. https://doi.org/10.1071/AP06088

Goldson SL, Bourdôt GW, Brockerhoff EG, Byrom AE, Clout MN, McGlone MS, Nelson WA, Popay AJ, Suckling DM, Templeton MD 2015. New Zealand pest management: current and future challenges. Journal of the Royal Society of New Zealand 45(1): 31-58. https://doi.org/1 $\underline{0.1080 / 03036758.2014 .1000343}$

Government Industry Agreement for Biosecurity Readiness and Response (GIA). 2020. The biosecurity story. Accessed December 2020 from http://www.gia.org.nz/ Biosecurity

Groenteman R, Forgie SA, Hoddle MS, Ward DF, Goeke DF, Anand N 2015. Assessing invasion threats: novel insectpathogen-natural enemy associations with native New Zealand plants in southern California. Biological Invasions 17: 1299-1305. https://doi.org/10.1007/ s10530-014-0804-0

Ho WH, Baskarathevan J, Griffin RL, Quinn BD, Alexander BJR, Havell D, Ward NA, Pathan AK 2019. First report of myrtle rust caused by Austropuccinia psidii on Metrosideros kermadecensis on Raoul Island and on $M$. excelsa in Kerikeri, New Zealand. Diseases Notes 103: 2128. https://doi.org/10.1094/PDIS-12-18-2243-PDN

International Plant Sentinel Network (IPSN). 2014. International Plant Sentinel Network. Accessed December 2020 from http://www.plantsentinel.org/ resources/

Kramer A, Hird A 2011. Building an international sentinel plant network. BG Journal 8(2): 3-6.

Landcare Research 2020. nzflora Myrtaceae. Accessed December 2020 from www.nzflora.info/factsheet/ taxon/Myrtaceae.html

Loope L 2010. A summary of information on the rust Puccinia psidii Winter (guava rust) with emphasis on means to prevent introduction of additional strains to Hawai'i: U.S. Geological Survey Open-File Report 20101082. Accessed May 2015 from http://pubs.usgs.gov/ of/2010/1082/

Mansfield S, McNeill MR, Aalders LT, Bell NL, Kean JM, Barratt BIP, Boyd-Wilson K, Teulon DAJ 2019. The value of sentinel plants for risk assessment and surveillance to support biosecurity. NeoBiota 48: 1-24. https://doi. org/10.3897/neobiota.48.34205

Marfleet K, Sharrock S 2020. The International Plant Sentinel Network: an update on phase 2. Sibbaldia: The International Journal of Botanic Garden 
Horticulture 18: 105-116. https://doi.org/10.24823/ Sibbaldia.2020.291

Ministry for Primary Industries (MPI). 2018. Biosecurity. Biosecurity New Zealand. Ministry for Primary Industries, Wellington, New Zealand. Accessed July 2019 from https://www.mpi.govt.nz/law-and-policy/ legal-overviews/biosecurity/).

Paap T, Burgess TI, Wingfield MJ 2017. Urban trees: bridgeheads for forest pest invasions and sentinels for early detection. Biological Invasions 19: 3515-3526. https:// doi.org/10.1007/s10530-017-1595-x

Redlich S, Clemens J, Bader MKF, Pendrigh D, Perret-Gentil A, Godsoe W, Teulon DAJ, Brockerhoff EG 2019. Identifying new associations between invasive aphids and Pinaceae trees using plant sentinels in botanic gardens. Biological Invasions 21: 217-228. https://doi.org/10.1007/ s10530-018-1817-X

Scholthof K 2007. The disease triangle: pathogens, the environment and society. Nature Reviews Microbiology 5: 152-156. https://doi.org/10.1038/nrmicro1596

Scott-Brown, AS, Hodgetts J, Hall, J, Simmonds MJS, Collins DW 2017. Potential role of botanic garden collections in predicting hosts at risk globally from invasive pests: a case study using Scirtothrips dorsalis. Journal of Pest Science 91: 601-611. https://doi.org/10.1007/s10340017-0916-2

Smith GR, Ganley BJ, Chagné D, Nadarajan J, Pathirana RN, Ryan J, Arnst EA, Sutherland R, Soewarto J, Houliston G, Marsh AT, Koot E, Carnegie AJ, Menzies T, Lee DJ, Shuey LS, Pegg GS 2020. Resistance of New Zealand provenance Leptospermum scoparium, Kunzea robusta, Kunzea linearis, and Metrosideros excelsa to Austropuccinia psidii. Plant Disease104(6): 1771-1780. https://doi. org/10.1094/PDIS-11-19-2302-RE

Soewarto J, Carriconde F, Hugot N, Bocs S, Hamelin C, Maggia L 2018. Impact of Austropuccinia psidii in New Caledonia, a biodiversity hotspot. Forest Pathology 48(2) e12402. https://doi.org/10.1111/efp.12402

Soewarto J, Sutherland R, Ganley B, du Plessis E, Barnes I, Wingfield M, Granados G 2019. MPI 18608 Project Report Topic 1.3 - Assessment of other myrtle rust biotypes. Biosecurity New Zealand Technical Paper No: 2019/35. https://myrtlerust.org.nz/assets/Uploads/ Assessment-of-other-myrtle-rust-biotypes.pdf

Teulon DAJ, Alipia TT, Ropata HT, Green JM, ViljanenRollinson SLH, Cromey MG, Arthur K, MacDiarmid RM, Waipara MW, Marsh AT 2015. The threat of myrtle rust to Māori taonga plant species in New Zealand. New Zealand Plant Protection 68: 66-75. https://doi. org/10.30843/nzpp.2015.68.5869

Teulon DAJ, Puketapu A, Ropata HT, Bicknell R 2019. Establishing a base for understanding the threat of the brown marmorated stink bug to plants of value to Māori. E whakarite ana he tūāpapa e mārama ai i ngā kino o te ngārara pīhau parauri ki ngā tipu e whai hua ki te Māori. New Zealand Plant Protection 72: 44-58. https://doi. org/10.30843/nzpp.2019.72.292

Tomoshevich M, Kirichenko N, Holmes K, Kenis M 2013. Foliar fungal pathogens of European woody plants in Siberia: An early warning of potential threats? Forest Pathology 
Appendix 1 Gardens that responded to our myrtle rust (MR) survey requests and the species* they reported.

\begin{tabular}{lll}
\hline Country/Garden & New Zealand Myrtaceae & $\begin{array}{l}\text { MR in } \\
\text { garden }\end{array}$
\end{tabular}

\section{Australia}

Auburn Botanical Gardens, NSW

Australian Botanic Garden, Mount Annon, NSW

Australian National Botanic Gardens ACT

\section{Boodoree Botanic Gardens, NSW}

Brisbane Botanical Gardens, QLD

Geelong Botanic Gardens, VIC

Hunter Region Botanic Gardens, NSW
None

None

Lophomyrtus bullata, possibly Kunzea ericoides ${ }^{1}$ \& Leptospermum scoparium

None

Commercial cultivars of Metrosideros Yes and nothing mature

M. excelsa, Lophomyrtus bullata,

$K$. ericoides

Leptospermum scoparium, M. excelsa Yes

No
Some infection of MR occurring on new growth flush but no evidence of significant dieback

Yes - See Table 2

New Zealand garden: See Table 2

K. ericoides ${ }^{1}$, Metrosideros cultivars, Leptospermum scoparium 'Nanum Rubrum'

Hobart, TAS

Tasmanian Arboretum, Devonport, TAS

Lophomyrtus bullata, Leptospermum scoparium
No

Yes

Yes

No MR observed on New Zealand species. For other species: removal and destruction of badly diseased plants and application of pesticides for those less affected

No MR observed on New Zealand species. Under prolonged drought conditions

Outbreaks of MR on L. obcordata Weekly monitoring, removal and/or pesticde applications for infected plants

No No MR in gardens
Used as sentinels but were free of myrtle rust

\section{United States}

National Tropical Botanical Garden,

Kalaheo, HI

Palomar College Arboretum, San

Marcos, CA

San Francisco Botanical Garden, CA

University of California, Berkeley, CA

Harold L. Lyon Arboretum, Honolulu, HI

\section{None}

M. excelsa, Leptospermum scoparium No

K. ericoides ${ }^{1}$, Lophomyrtus $\times$ ralphii, Lophomyrtus bullata, Lophomyrtus obcordata, M. carminea, M. excelsa, M. kermadecensis, M. robusta,

\section{M. umbellata}

K. ericoides ${ }^{1}$, Lophomyrtus $\times$ ralphii, Leptospermum scoparium, Lophomyrtus obcordata

M. kermadecensis

No

None on myrtle rust

Honolulu Botanical Gardens Wahiawa, $\mathrm{HI}$ UC Santa Cruz Arboretum, CA
M. excelsa

Lophomyrtus $\times$ ralphii, Lophomyrtus obcordata

\section{Japan}

